\title{
Harita Beceri Düzeyleri İle Öğrenme Stilleri Arasındaki İlişkinin Belirlenmesi Üzerine Bir İnceleme
}

\section{Özet}

Hakan KOÇ*

$\mathrm{Bu}$ çalışmanın amacı, harita beceri düzeyleri puanı ile öğrenme stilleri ve okul türü arasında bir ilişkinin olup olmadığını belirlemektir. Bu araştırma, öğrencilerin harita beceri düzeyleri ile öğrenme stilleri arasındaki ilişkiyi incelemek üzere planlanmış tarama modelinde betimsel bir çalışmadır. Araştırmada öğrencilerin öğrenim gördükleri okul ile öğrenme döngüsünün aşamaları ve harita beceri puanları arasındaki farkın belirlenmesi amacıyla Tek Yönlü Varyans Analizi kullanılmıştır. Tek Yönlü Varyans Analizi sonucu saptanan farklılığın hangi düzeyden kaynaklandığını belirlemek amacıyla da anlamlılık testlerinden Tukey HSD kullanılmıştır. Öğrenme stili ile öğrencilerin harita beceri düzeyleri arasında anlamlı bir farklılık tespit edilmemiştir. Buna karşın okul türü ile harita beceri düzeyleri arasında anlamlı bir fark bulunmuştur. Anlamlı fark fen ve anadolu liselerinin lehinedir.

Anahtar Kelimeler: Harita, Harita Becerileri, Öğrenme Stilleri

\section{A Study on Determining The Relation Between The Level of Mapping Skills and Learning Styles}

\begin{abstract}
The purpose of the present study is to determine whether there is a relationship between the levels of the mapping skills ratings, learning skills and the type of the school. It is a descriptive basing on reviewing model which was designed to investigate the relationship between the levels of the mapping skills and learning styles. In the study one-way ANOVA was used in order to determine the difference between the school types, the stages of the learning cycles and the mapping skills ratings. Following the

\footnotetext{
*Yrd. Doç. Dr. Hakan KOÇ, Cumhuriyet Üniversitesi Eğitim Fak. Ortaöğretim Sosyal Alanlar Coğrafya Eğitimi Anabilim Dalı Öğretim Üyesi, Sivas, hakankoc66@cumhuriyet.edu.tr (Bu çalışma Coğrafyacılar Derneğinin düzenlediği ylllık kongrede bildiri olarak sunulmuştur. 19-21 Haziran 2013)
} 
determination of the difference as a result of the one-way ANOVA, Tukey HSD, which is among the tests of significance, was employed in order to determine from which level the detected difference took its roots. No meaningful difference was determined between learning styles and the levels of mapping skills of the learners. On the other hand, a meaningful difference was observed between the school types and the levels of mapping skill. This meaningful difference is in favour of the science and Anatolian high schools.

Key words: Map, Mapping Skills, Learning Styles

\section{Giriş}

Son yıllarda eğitim alanında oldukça geniş kabul gören yapılandırmacı eğitim anlayışı farklı disiplinlerin öğretim programlarına yansitılmış veya fizik, kimya, matematik, tarih ve biyoloji gibi disiplinlerde de yansitılmaya devam edilmektedir.

2005 yılında uygulanmaya başlanan coğrafya dersi öğretim programı da yapılandırmacı eğitim kuramına göre düzenlenen öğretim programlarımızdan birisidir. $\mathrm{Bu}$ program dikkatlice incelendiğinde; aşağıdaki özellikler hemen herkes tarafından fark edilebilir.

$\checkmark$ Öğrencinin bilgiyi aktif olarak yapılandırmasına olanak sağlayan ve öğrencilerin bireysel farklılıklarına uygun etkinlik örneklerine ve öğretim yöntemlerine genişçe yer vermesi.

$\checkmark$ Öğrenenlerin bilgi, davranış, algı ve tutumlarını ölçecek farklı ölçme ve değerlendirme araçlarına yer vermesi.

$\checkmark$ Konu, ünite yerine kazanımlara yer vermesi, kazanımların verilişinde de yakından uzağa ve basitten karmaşığa ilkelerinin esas alınması.

$\checkmark \quad$ Ezberci eğitim yerine beceri temelli eğitime yer vermesi. Coğrafya öğretim programında eleştirel düşünme, problem çözme, karar verme gibi genel becerilerin yanı sıra harita, tablo grafik hazırlama ve yorumlama becerileri, coğrafi sorgulama becerisi, kanıt kullanma, arazi çalışma ve değişim ve sürekliliği algilama gibi coğrafi becerilerde yer almaktadır.

“Coğrafya bilimi; günümüz dünyasından beslenerek yeni yaklaşımlar geliştirmesi gerekliliği açısından öğrencilerin, günümüz dünyasını anlamaya yönelik bakış açıları geliştirmelerine yardımcı olur. Öğrenciler coğrafya eğitimi ile dünyayı algılama, anlama ve değerlendirme açısından yaşadığ alandan küresel ölçeğe doğa ve insana ait sistemler, süreçler ve dokulara 
yönelik coğrafi bilinç kazanır" (MEB, 2005:14). Coğrafi bilinci kazanılması ise coğrafi becerilerle mümkündür.

$\mathrm{Bu}$ coğrafi beceriler içerisinde en kapsamlı ve en yaygın kullanılanı harita becerisidir. Çünkü coğrafyacıların olay, olgu ve özelliklerin dağılışını göstermede kullandıkları en önemli öğretim araçları da haritalardır. “Coğrafyacıların üstlendikleri önemli görevlerden biri de olgu, olay ve özelliklerin dağılışlarını haritalar yardımıyla göstererek bu dağılışların farklılık göstermesini neden sonuç ilişkisi içerisinde öğrencilerin analiz, sentez etmesini sağlamaktır. Böylelikle haritalar yardımıyla ilk, orta ve yüksek öğretim kurumlarında öğrenim gören öğrencilerin mekân algısı ve bilincini geliştirmektir. Haritalar çocuklarda mekân algisı oluşturur" (Koç,2008:6).

Coğrafi beceriler içerisinde harita becerisi çok kapsamlı bir beceridir. Kendi içerisinde birtakım alt becerileri içerir. Bu beceriler şunlardır:

- Sembolleri Anlama ve Yorumlama Becerisi: Sembolsüz harita düşünülemez. Semboller, haritaların okunmasını sağlar. Kartograflar semboller yardımıyla olay, olgu ve özellikleri haritalara kodlarlar. Harita kullanıcıları da bu sembollerden yararlanarak kodlanılmış olay, olgu ve özellikleri anlamlandırır.

- Harita Okuma ve Yorumlama Becerisi: "Kartograflar tarafından kodlanmış bilgi içeren haritalar nasıl okunur? Harita okumanın, kitap okuma gibi bilinen bir yöntemi bulunmamaktadır. Örneğin, sayfanın solundan sağına okuma gibi. Bu açıdan bakıldığında bir haritanın okunması şüphesiz bir kitabın okunması gibi düşünülemez" ( Weeden, 1997:169).

"Gözlerimiz yardımıyla harita üzerinde algıladıklarımız renk, doku, şekil, boyut vb. özelliklerine göre düzenlenen bilgiler görme sinirleri vasıtasıyla beyindeki görme korteksine yönlendirilir. Harita okumada ilk olarak haritanın lejantında yer alan renk, şekil ve sembollerle vb. şekilde kodlanmış bilgilerin neyi ifade ettiğine bakılır. Lejanttaki sembol ve renkler haritanın türüne göre de değişmektedir. Gözün retinası tarafından algılanan harita üzerindeki olgu, olay ve bilgilerin görme alanından ilk basamağına doğru hareket edildiğinde amaç zıt bilgilerin çıkarılması (yoğunluklar ve dalga boylarındaki farklılıklar bakımından) ve sınırların, bölgelerin ve şekillerin meydana getirilmesi için bu bilgilerin gruplandırılmasıdır. Harita okuyucularının harita üzerine aktarılan olay, olgu ve bilgileri hemen fark etmesi ve gruplandırması için kartografların en önemli harita unsurları arasında mutlak suretle zıtlık oluşturması gerekecektir. Harita üzerindeki doğal ve beşeri unsurları gösterebilmek için kullanılan şekil, semboller ve bunların benzerleri; yakınlık, benzerlik, tamamlama ve basitlik ilkelerine 
göre gruplandırılır. Oluşturulan bu gruplar bir sıra ölçüsünde değerlendirilir. Örneğin gruplara ayrılan renk basamaklarında koyu tonlar ölçünün en yüksek değerini gösterir. Benzerlik ve farklılık teşkil eden harita alanındaki ilginç olgu, olay ve özellikler üzerine odaklanılır ve kodlanılmış bilgilerden elde edilen bulgular dâhilinde yorumlanır" (Koç,2010:156).

- Profil Çıkarma Becerisi: "Perspektif nesnelerin görünümünü üç boyutlu olarak düz bir yüzeyde, yani iki boyuta indirgeyerek göstermeye yarayan izdüşümdür. Perspektif nesnelerin farklı bakış açılarından tanınabilmesi ya da kavranması yeteneğidir. Bu beceride öğrencilerin beceri kazanması genellikle görüntüyü perspektif bakış açısı yerine profilden tanımlar. Yakın çevre, uygulamaya dayalı deneyimler ve havadan alınan fotoğrafların kullanılması bu becerinin öğreniminde öne çıkarılmalıdır"(McClure, 1992: 106).

- Yön Bulma Becerisi: "Yön bir yere nasıl varacağınız ve ne yapacağınızı bildiren talimatlardır" ( Demirkaya ve Diğ., 2004: 40). "Yön belirtme ( yön saptama, yön bulma) bir dağa, tepeye, bir yapıya ya da bir yeri belli her hangi bir nesneye göre yer ve yönün saptanmasıdır. Astronomi yöntemleri kullanılarak, başka bir deyimle belirli gök cisimleri (Güneş, Kutup Yıldızı vb.) gözlemlenerek yapılır" (Sanır, 2000: 293).

- Uzaklık, Alan, Yükselti ve Eğimi Bulma Becerisi: Bu beceri düzlem üzerinde $\mathrm{cm}$ veya $\mathrm{mm}$ ile gösterilen mesafe ile arazi üzerindeki gerçek mesafe arasında ilişki kurabilmeyi kapsar. Ayrıca bu beceri $\mathrm{cm}, \mathrm{km}, \mathrm{cm}^{2}$, $\mathrm{km}^{2}$ gibi birimlerden yararlanarak bir takım matematiksel işlemleri yapabilmeyi içermektedir.

- Konum ve Koordinat Belirleme Becerisi: Bu beceri yeryüzünde bulunan bir noktanın koordinat sistemiyle, dünya üzerindeki yerini tespit edebilmeyi içerir.

- Ölçek Kullanma Becerisi: Bu beceri ölçek değiştikçe değişen özellikleri anlayabilmeyi ve ölçek yardımı ile birtakım matematiksel işlemleri yapabilmeyi içerir.

Harita becerisi eğitimi alan bireyler aynı sınıfta dahi olsa her bir bireyin harita beceri başarı düzeyi birbiriden farklılık gösterebilir. Öğrencilerin başarı düzeylerinin farklılık göstermesinde pek çok değişken olabilir. Öğrencinin derse hazır bulunuşluk düzeyi, sınıfın fiziki koşulları, öğrencinin derse ve konuya olan ilgi ve tutumu, günün saati, öğrencinin fizyolojik ve psikolojik durumu vb. faktörler bireyin başarı düzeyini doğrudan ve dolaylı olarak etkileyen faktörlerden birkaçıdır. Öğrencinin başarı düzeyi üzerinde etkili olan bu değişkenlere "öğrenme değişkeni de" 
Uşak Üniversitesi Sosyal Bilimler Dergisi

$2013,6 / 4$

H. KOÇ

denilmektedir. Öğrenme değişkenleri, öğrencinin öğrenme durumunu, dolayısıyla başarı düzeyini olumlu ya da olumsuz olarak etkiler. Öğrenme değişkenini etkileyen etmenlerden birisi de öğrenme stilidir.

Sınıf içi öğrenme-öğretme etkinliklerinin öğrencinin öğrenme stiline uygun olması, öğrencinin öğrenmesini kolaylaştıracak ve akademik başarısının artmasına katkı sağlayacaktır. Diğer taraftan, kendi stilinin özelliklerini bilen bir öğretici stillerindeki karşılıklarını bularak daha verimli bir öğretim hizmeti tasarlayabilir. Hatta vereceği her ders için ayrı ayrı kendine özgü ders tasarımları da geliştirebilir (Babadoğan, 2000: 62-63).

Öğrenme stili, bilgiyi kavramada ve işlemede kişisel olarak tercih edilen bir yol / yöntemdir (Kolb, 1984; Baykara Pehlivan, 2010:751).

Kolb'a göre, değiştiren, özümseyen, ayrıştıran ve yerleştiren stil olmak üzere dört öğrenme stili vardır.

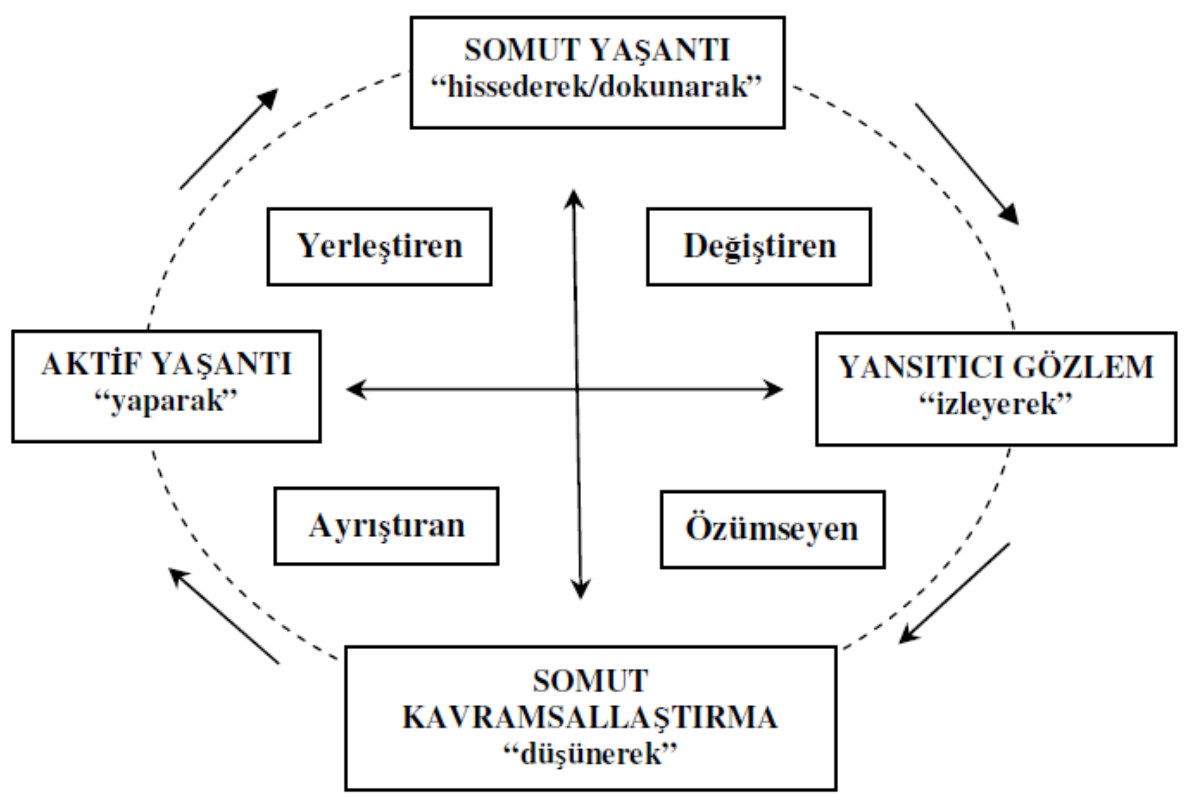

Şeki1: Yaşantısal öğrenme halkası (Joy ve Kolb, 2007; Şenyuva,2009: 250).

- Değiştiren Öğrenme Stili: $\mathrm{Bu}$ öğrenme stilinde baskın öğrenme yeteneği somut yaşantılar (hissederek) ile yansıtıcı gözleme (izleyerek ve düşünerek) dayanır. Bu öğrenme stiline sahip bireyler yeni görüş ve fikirlere açıktır. Bunun yanı sıra fikirleri paylaşırlar ve dinleyerek öğrenirler. Olaylar karşısında harekete geçmek yerine gözlem yapmayı tercih ederler. Tarafsız yargılarda bulunurlar. Bu özellikler bu öğrenme stiline sahip bireylerin güçlü yönleridir. $\mathrm{Bu}$ öğrenme stiline sahip bireylerin zayıf yönleri ise 
seçenekler arasında seçim yapma konusunda zorlanmalarıdır. "Bu tip öğrenenlerin favori sorusu niçindir? Öğretmenler bu tip öğrenenlere gerçek bir sebep gösterme ihtiyacı hissederler" (McCarthy, 1985:61).

- Özümseyen Öğrenme Stili: Bu öğrenme stilinde baskın öğrenme yeteneği soyut kavramsallaştırma (düşünerek) ile yansıtıcı gözlemdir (izleyerek ve düşünerek). Bu öğrenme stilindeki bireyler gözlemlerini bildikleriyle bütünleştirerek kuramlar oluştururlar. Karar vermeden önce ilgili olay yâda olguyu dikkatli bir şekilde izlerler, olay yâda olguya farklı açıklardan bakarlar ve olay yâda olguyu özümseyerek olay yâda olgu hakkında bir sonuca varırlar. Bu öğrenme stiline sahip bireyler geniş kapsamlı bilgileri anlama ve bunları mantıksal bir bütün haline getirme konusunda başarılıdırlar. Bu tip öğrenme stiline sahip bireylerin güçlü yönleri, planlama yapma, model oluşturma ve kuram geliştirmeleridir. Zayıf yönleri ise hayal kurma, pratik uygulama yapmalarıdır. " $\mathrm{Bu}$ tip öğrenenlerin favori sorusu ne sorusudur? Öğretmenler bu tip öğrenenlere olgunun derinlemesine anlaşılmasını sağlayan gerçekleri anlatma ihtiyacı hissederler" (McCarthy, 1985:61).

- Ayrıştıran Öğrenme Stili: “Baskın öğrenme yeteneği soyut kavramsallaştırma (düşünerek) ile aktif yaşantılardır (yaparak). Kuram ve uygulamayı bütünleştirirler. Kuramları test ederek öğrenirler. En iyi elle yapılabilen tekniklerle öğrenirler. Problem çözmede mükemmeldirler. Deney yaparlar ve yaptıkları deneyler üzerinde fikirler yürütürler. Nesnelerin, formüllerin nasıl çalıştı̆̆ını bilmek isterler"(Baykara Pehlivan, 2010:752). "Bu tip öğrenenlerin favori sorusu nasıl sorusudur? Öğretmenler bu tip öğrenenlere bir şeyleri denemesine, deney yapmalarına müsaade etme ihtiyacı hissederler" (McCarthy, 1985:61).

- Yerleştiren Öğrenme Stili: Bu öğrenme stilinde baskın öğrenme yeteneği somut yaşantılar (hissederek-düşünerek) ile aktif yaşantılardır (yaparak). Yaparak ve hissederek öğrenme söz konusudur. Bu öğrenme stiline sahip bireyler izleme yerine pratik uygulamalar yaparlar ve yaşantı ve uygulamayı bütünleştirirler. Deneme-yanılma yoluyla öğrenirler. Bu öğrenme stiline sahip bireylerin güçlü yanları başladıkları bir işi tamamlamaları ve amaçlarına ulaşmak için risk almalarıdır. Zayıf yönleri ise, amaçsız aktiviteler yapma, işini zamanında bitirmeme, pratik olmayan uygulamalar yapma ve amaca yönelik hareket etmemeleridir. "Bu tip öğrenenlerin favori sorusu ise ne olur? sorusudur. Öğretmenler bu tip öğrenenlere kendi kendilerine öğrenmelerine izin verme ihtiyacı hissederler" (McCarthy, 1985:62). 
Öğrencilerin kalıtsal özelliklerindeki, geçmiş yaşantıları (çocukluk, okul vb. diğer yaşantılar) ile şimdiki yaşantılarındaki (sosyal çevre ve yaptığ gerektirdiği beceriler, anlayışlar) farklılıklar ve öğrenme-öğretme sürecindeki yaşantılar / deneyimler, bu dört öğrenme döngüsünün aşamalarından birinin baskın olmasına neden olmaktadır. (Şenyuva, 2009:252)

\section{Araştırmanın Amacı}

$\mathrm{Bu}$ çalışmanın amacı, harita beceri düzeyleri puanı ile öğrenme stilleri ve harita beceri düzeyleri puanı ile okul türü arasında bir ilişkinin olup olmadığını belirlemektir.

\section{Araştırma Modeli}

$\mathrm{Bu}$ araştırma, öğrencilerin harita beceri düzeyleri ile öğrenme stilleri arasındaki ilişkiyi incelemek üzere planlanmış tarama modelinde betimsel bir çalışmadır. "Tarama modelleri; geçmişte veya halen var olan bir durumu, var olduğu şekli ile betimlemeyi amaçlayan araştırma yaklaşımıdır. Araştırmaya konu olan olay, birey ya da nesne, kendi koşulları içinde ve olduğu gibi tanımlanmaya çalışılır. Onları herhangi bir şekilde değiştirme, etkileme çabası gösterilmez" (Karasar,1991:77).

\section{Çalışma Grubu}

Araştırmanın çalışma grubunu Abdülsamed İmam Hatip Meslek Lisesi (85 kişi), Cumhuriyet Anadolu Lisesi (85 kişi) ve Sivas Fen Lisesi'nde (87 kişi) öğrenim gören 9. sınıf öğrencilerinden toplam 257 kişi oluşturmaktadır.

\section{Araştırmanın Veri Toplama Araçları}

Araştırmanın verisi, iki gruptan oluşmaktadır. Bunlardan biri öğrencilerin öğrenme stilleri puanları, diğeri harita becerileri testi başarı puanlarıdır. Öğrenme stilleri puanları için Öğrenme Stilleri Ölçeği (LSI), harita becerileri başarı puanları için de Harita Beceri Düzeyleri Testi kullanılmıștır.

Araştırmada, öğrencilerin öğrenme stillerine ilişkin veriler Kolb tarafından geliştirilen, Aşkar ve Akkoyunlu (1993) tarafından Türkçeye uyarlama çalışmaları yapılarak geçerlilik ve güvenirliği incelenen "Kolb Öğrenme Stili Envanteri" ile toplanmıştır.

Harita Becerileri Başarı Testi, öğrencilerin sembolleri anlama ve yorumlama, harita okuma ve yorumlama, yön bulma, profil çıkarma, konum ve koordinat belirleme, ölçek kullanma, uzaklık ve alan ölçme, gibi becerileri 
Uşak Üniversitesi Sosyal Bilimler Dergisi

$2013,6 / 4$

H. KOÇ

ölçen çoktan seçmeli 24 madde ve beş seçenekten oluşan bir ölçme aracıdır. $\mathrm{Bu}$ ölçme aracı araştırmacı tarafından hazırlanmıştır. Ölçme aracının güvenirlik katsayısı KR20: 9999 bulunmuştur.

\section{Verilerin Analizi ve Kullanılan İstatistiksel Yöntem}

Veriler, bilgisayar ortamında SPSS 18.0 paket programı kullanılarak değerlendirilmiştir. Öğrencilerin öğrenim gördükleri okul ile öğrenme döngüsünün aşamaları ve harita beceri puanları arasındaki farkın belirlenmesi amacıyla Tek Yönlü Varyans Analizi kullanılmıştır. Tek Yönlü Varyans Analizi sonucu saptanan farklılığın hangi düzeyden kaynaklandığını belirlemek amacıyla anlamlılık testlerinden Tukey HSD kullanılmıştır.

\section{Bulgular ve Yorum}

\section{Harita Beceri Puanlarının Öğrenme Stili Değişkenine Göre Farklılaşıp}

Farklılaşmadığına İlişkin Bulgular: Harita beceri puanlarının öğrenme stili değişkenine göre farklılaşıp farklılaşmadığa ilişkin tek yönlü varyans analiz sonuçları Tablo 1'de yer almaktadır.

Tablo 1:Harita Beceri Puanlarının Öğrenme Stili Değişkenine Göre Anova Testi Sonuçları

\begin{tabular}{|c|c|c|c|c|c|c|c|c|c|}
\hline Değişken & Öğreme St. & $\mathbf{n}$ & $\bar{x}$ & SS & & KT & SD & $\mathbf{F}$ & $\mathbf{P}$ \\
\hline Harita & Değiştiren & 55 & 46 &, 22 & Grup. arası & ,089 & 3 &, 580 & 629 \\
\hline \multirow{4}{*}{$\begin{array}{c}\text { Becerileri } \\
\text { Toplam } \\
\text { Puanı }\end{array}$} & Özümseyen & 118 &, 50 &, 22 & Gruplar içi & 12,85 & 250 & & \\
\hline & Ayrıştıran & 54 &, 51 & ,21 & Toplam & 12,94 & 253 & & \\
\hline & Yerleştin & 27 &, 50 & ,26 & & & & & \\
\hline & Toplam & 254 & 49 &, 22 & & & & & \\
\hline \multirow{5}{*}{$\begin{array}{c}\text { Sembolleri } \\
\text { Anlama }\end{array}$} & Değiştiren & 55 &, 57 & 30 & Grup. arası & ,267 & 3 & 1,110 & ,346 \\
\hline & Özümseyen & 121 & 63 & 28 & Gruplar içi & 20,24 & 253 & & \\
\hline & Ayrıştıran & 54 & 65 & ,24 & Toplam & 20,51 & 256 & & \\
\hline & Yerleştiren & 27 &, 58 & 28 & & & & & \\
\hline & Toplam & 257 & ,62 & ,28 & & & & & \\
\hline Harita & Değiştiren & 55 & ,41 & 30 & Grup. arası & ,232 & 3 & ,806 & ,492 \\
\hline \multirow{2}{*}{$\begin{array}{c}\text { Okuma } \\
\text { ve }\end{array}$} & Özümseyen & 121 & 41 & ,31 & Gruplar içi & 24,29 & 253 & & \\
\hline & Ayrıştıran & 54 & ,43 & ,31 & Toplam & 24,53 & 256 & & \\
\hline \multirow{2}{*}{$\begin{array}{c}\text { Yorumla } \\
\text { ma }\end{array}$} & Yerleştiren & 27 &, 51 & ,30 & & & & & \\
\hline & Toplam & 257 & ,43 &, 30 & & & & & \\
\hline Profil & Değiştiren & 55 &, 50 & ,33 & Grup. arası & ,356 & 3 & 1,124 & 340 \\
\hline \multirow[t]{4}{*}{ Çıkarma } & Özümseyen & 119 &, 59 & ,31 & Gruplar içi & 26,46 & 251 & & \\
\hline & Ayrıştıran & 54 & 61 & ,32 & Toplam & 26,82 & 254 & & \\
\hline & Yerleştiren & 27 &, 59 & 31 & & & & & \\
\hline & Toplam & 255 &, 57 &, 32 & & & & & \\
\hline Yön & Değiştiren & 55 &, 55 & ,37 & Grup. arası & ,598 & 3 & 1,703 & 167 \\
\hline Bulma & Özümseyen & 121 & ,64 &, 33 & Gruplar içi & 29,62 & 253 & & \\
\hline
\end{tabular}


Uşak Üniversitesi Sosyal Bilimler Dergisi

$2013,6 / 4$

H. KOÇ

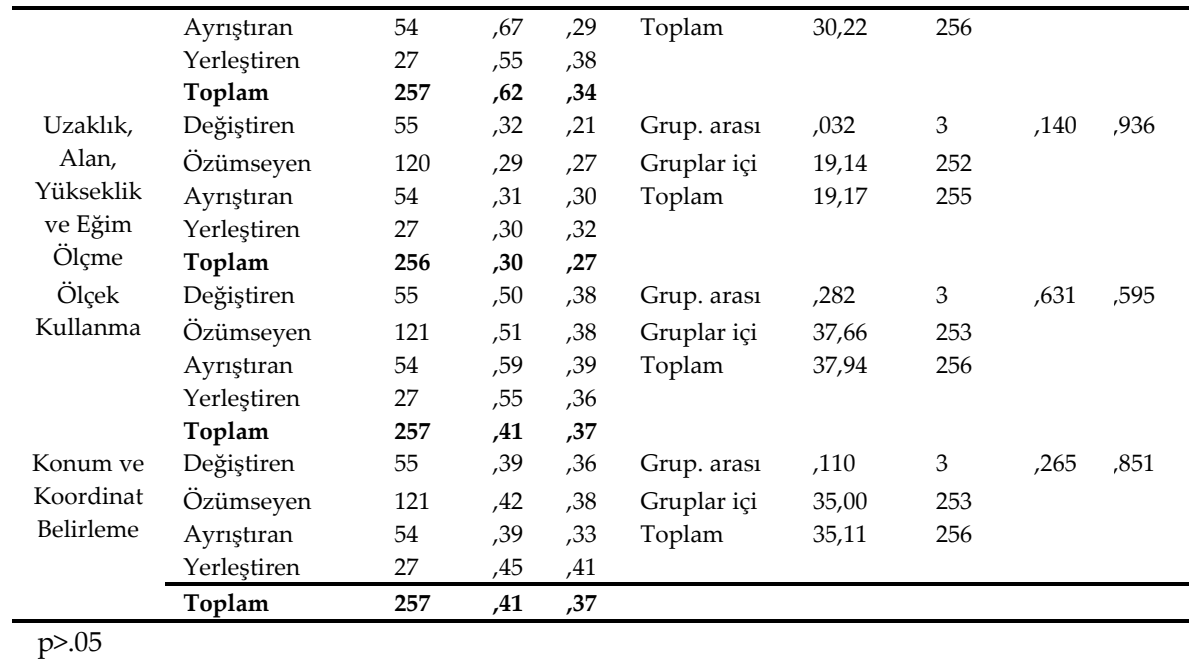

Tablo1'den anlaşılacağ beceri puanlarının öğrenme stili değişkenine göre anlamlı bir farklılık oluşturmadığ görülmektedir ( $\mathrm{F}=, 580 \quad \mathrm{p}>.05)$. Benzer şekilde ortaöğretim öğrencilerinin sembolleri anlama, harita okuma ve yorumlama, profil çıkarma, yön bulma, ölçek kullanma, uzaklık, alan, yükselti ve eğim ölçme ve konum ve koordinat belirleme puanlarının da öğrenme stili değişkenine göre anlamlı bir farklılık oluşturmadığı tablo 1'den anlaşılmaktadır.

Harita beceri puanlarının okul türü değişkenine göre farklılaşıp farklılaşmadığına ilişkin bulgular: Harita beceri puanlarının okul türü değişkenine göre farklılaşıp farklılaşmadığa ilişkin tek yönlü varyans analiz sonuçları Tablo 2' de yer almaktadır.

Tablo 2: Harita Beceri Puanlarmın Okul Türü Değişkenine Göre Anova Testi Sonuçları

\begin{tabular}{|c|c|c|c|c|c|c|c|c|c|}
\hline Değişken & Okul Türü & $\bar{n}$ & $\overline{\bar{x}}$ & SS & & KT & SD & $\bar{F}$ & $\mathbf{P}$ \\
\hline Harita Becerileri & Meslek & 83 & 25 & 10 & Grup. arası & 7,23 & 2 & & 000 \\
\hline \multirow[t]{4}{*}{ Toplam Puanı } & Lisesi & & & & & & & 159,00 & \\
\hline & $\begin{array}{l}\text { Andolu } \\
\text { Lisesi }\end{array}$ & 84 & 61 & ,20 & Gruplar içi & 5,70 & 251 & & \\
\hline & Fen Lisesi & 87 & 61 & 12 & Toplam & 12,94 & 253 & & \\
\hline & Toplam & 254 & ,49 & 22 & & & & & \\
\hline \multirow{6}{*}{$\begin{array}{c}\text { Sembolleri } \\
\text { Anlama }\end{array}$} & Meslek & 85 & ,36 & ,24 & Grup. arası & 8,43 & 2 & 88,72 &, 000 \\
\hline & Lisesi & & & & & & & & \\
\hline & Andolu & 85 & ,70 & ,22 & Gruplar içi & 12,07 & 254 & & \\
\hline & Lisesi & & & & & & & & \\
\hline & Fen Lisesi & 87 & ,78 & 17 & Toplam & 20,51 & 256 & & \\
\hline & Toplam & 257 & 62 & 28 & & & & & \\
\hline Harita Okuma & Meslek & 85 & ,23 & ,25 & Grup. arası & 5,46 & 2 & 36,36 &, 000 \\
\hline
\end{tabular}


Uşak Üniversitesi Sosyal Bilimler Dergisi

$2013,6 / 4$

H. KOÇ

\begin{tabular}{|c|c|c|c|c|c|c|c|c|c|}
\hline \multirow{4}{*}{$\begin{array}{c}\text { ve } \\
\text { Yorumlama }\end{array}$} & Lisesi & & & & & & & & \\
\hline & Andolu & 85 &, 59 & ,28 & Gruplar içi & 19,07 & 254 & & \\
\hline & $\begin{array}{l}\text { Lisesi } \\
\text { Fen Lisesi }\end{array}$ & 87 & 46 & 28 & & & 256 & & \\
\hline & Toplam & 257 & 43 & ,30 & & & & & \\
\hline \multirow{6}{*}{$\begin{array}{l}\text { Profil } \\
\text { Çıkarma }\end{array}$} & Meslek & 84 & ,30 & 24 & Grup. arası & 9,11 & 2 & 64,87 & ,000 \\
\hline & Lisesi & & & & & & & & \\
\hline & Andolu & 84 & ,70 & ,28 & Gruplar içi & 17,70 & 252 & & \\
\hline & Lisesi & & & & & & & & \\
\hline & Fen Lisesi & 87 & 72 & ,25 & Toplam & 26,82 & 254 & & \\
\hline & Toplam & 255 & ,57 & ,32 & & & & & \\
\hline \multirow{5}{*}{$\begin{array}{c}\text { Yön } \\
\text { Bulma }\end{array}$} & Meslek & 85 & ,31 & 28 & Grup. arası & 12,39 & 2 & 88,26 & ,000 \\
\hline & Lisesi & & & & & & & & \\
\hline & $\begin{array}{l}\text { Andolu } \\
\text { Lisesi }\end{array}$ & 85 & 72 & 28 & Gruplar içi & 17,83 & 254 & & \\
\hline & Fen Lisesi & 87 & 82 & ,22 & Toplam & 30,22 & 256 & & \\
\hline & Toplam & 257 & 62 & ,34 & & & & & \\
\hline \multirow{5}{*}{$\begin{array}{l}\text { Uzaklık, Alan, } \\
\text { Yükseklik ve Eğim } \\
\text { Ölçme }\end{array}$} & Meslek & 84 & ,17 & 18 & Grup. arası & 2,35 & 2 & 17,71 & ,000 \\
\hline & Lisesi & & & & & & & & \\
\hline & $\begin{array}{l}\text { Andolu } \\
\text { Lisesi }\end{array}$ & 85 & 41 & ,32 & Gruplar içi & 16,82 & 253 & & \\
\hline & Fen Lisesi & 87 &, 32 & ,25 & Toplam & 19,17 & 255 & & \\
\hline & Toplam & 256 & ,30 & 27 & & & & & \\
\hline \multirow[t]{5}{*}{ Ölçek Kullanma } & $\begin{array}{l}\text { Meslek } \\
\text { Lisesi }\end{array}$ & 85 & ,27 & 24 & Grup. arası & 10,32 & 2 & 47,47 & ,000 \\
\hline & Andolu & 85 &, 56 & ,39 & Gruplar içi & 27,62 & 254 & & \\
\hline & Lisesi & & & & & & & & \\
\hline & Fen Lisesi & 87 & ,76 & ,33 & Toplam & 37,94 & 256 & & \\
\hline & Toplam & 257 & ,53 & ,38 & & & & & \\
\hline Konum ve & Meslek & 85 & ,09 & 16 & Grup. arası & 13,28 & 2 & 77,28 & ,000 \\
\hline Koordinat & Lisesi & & & & & & & & \\
\hline \multirow[t]{4}{*}{ Belirleme } & Andolu & 85 & ,62 & ,35 & Gruplar içi & 21,83 & 254 & & \\
\hline & Lisesi & & & & & & & & \\
\hline & Fen Lisesi & 87 &, 52 & ,32 & Toplam & 35,11 & 256 & & \\
\hline & Toplam & 257 & ,41 &, 37 & & & & & \\
\hline
\end{tabular}

Öğrencilerin toplam harita beceri düzeyi puanlarının okul türü değişkenine göre tek yönlü varyans analizi sonuçları, lise türleri arasında anlamlı bir farklılaşma olduğunu göstermektedir $(\mathrm{F}=159,00 \mathrm{p}<.05)$. Anlamlı farklılıkların hangi gruplar arasında olduğunu belirlemek için yapılan Tukey HSD testinde anlamlı farklılığın fen lisesi ve meslek lisesi ile anadolu lisesi ve meslek lisesi arasında olduğu ve bu farklılığın fen ve anadolu liselerinin lehine olduğu görülmektedir. Benzer sonuç, sembolleri anlama, profil çıkarma, yön bulma, uzaklık, alan, eğim ve yükselti bulma ve konum ile koordinat bulma beceri puanları içinde söylenebilir. (Tablo 2).

Ancak harita okuma ve yorumlama ile ölçek kullanma beceri puanlarında Anadolu ve fen liseleri arasında anlamlı bir farklılaşma olduğu görülmektedir. Harita okuma ve yorumlama becerisinde anadolu liselerinin 
lehine, ölçek kullanmada ise fen liselerinin lehine anlamlı bir farklılık söz konusudur.

Anlamlı farklılıklar meslek lisesi ile fen lisesi ve meslek lisesi ile anadolu lisesi arasındadır.

\section{Tartışma}

Bahar, Özen ve Gülaçtı (2009: 69-86) “Eğitim Fakültesi Öğrencilerinin Cinsiyet ve Branşa Göre Akademik Başarı Durumları İle Öğrenme Stillerinin İncelenmesi" isimli çalışmalarında, eğitim fakültesi öğrencilerinin cinsiyet ve kayitlı olunan programa göre öğrenme stillerini tespit etmeye çalışmışlardır. Araştırmanın bulgularına dayalı olarak, öğrenme stillerinin cinsiyete göre farklı olmadığı ancak öğrencilerin kayıtlı olunan programa göre öğrenme stillerinin farklı olduğu tespit etmişlerdir.

Özen (2011:1-20) "Sosyal Bilgiler Eğitimi Öğretmenliği Öğrencilerinin Öğrenme Stilleri ve Bunların Çeşitli Değişkenlerle İlişkisi” isimli çalışmasında öğrenme stillerinin cinsiyete göre farklılık göstermediği, Sosyal Bilgiler Eğitimi Öğretmeni adaylarının çoğunluğunun ayrıştırıcı ve özümseyici öğrenme stillerine sahip olduklarını ve bu öğrencilerin öğrenme stillerinin mezun oldukları lisenin öğrenim türüyle anlamlı bir ilişki göstermediğini ifade etmektedir. Öğrencilerin baskın olan öğrenme stil türünün özümseyen olması bu yapılan çalışma ile benzerlik göstermektedir.

Kaya ve Diğ. (2012: 131-146) yapmış oldukları çalışmada; Harran Üniversitesi Sınıf Öğretmenliği, Beden Eğitimi ve Spor Öğretmenliği, Din Kültürü ve Ahlak Bilgisi Öğretmenliği branşlarında öğrenim gören öğretmen adaylarının cinsiyet, akademik başarıları ile öğrenme stilleri arasında anlamlı bir fark bulunamamışlardır. Bu çalışmada da öğrenme stilleri ile harita beceri düzeyleri arasında anlamlı bir fark bulunmamıştır.

Yazıcı ve Sulak (2008:217-236) “Öğrenme stilleri ile ilköğretim beşinci sınıf matematik dersindeki başarı arasındaki ilişki" isimli çalışmasında öğrencilerin baskın öğrenme stili olarak ayrıştırıcılar ve özümleyiciler öğrenme stillerini tercih ettikleri gözlemlemişlerdir.

Yazıcılar ve Güven (2009:9-23) “Öğrenme Stili Özelliklerinin Dikkate Alındığı Öğretim Etkinliklerini Uygulamanın Akademik Başarı, Tutumlar ve Hatırda Tutma Düzeyi Üzerindeki Etkisi" isimli çalışmalarında, farklı öğrenme stil boyutlarındaki öğrencilerin özelliklerine uygun olarak hazırlanan öğretim etkinlikleri uygulamak, öğrencilerin Sosyal Bilgiler dersinde akademik başarılarını artırdıklarını tespit etmişlerdir.

Yenice ve Saracaoğlu (2009:162-173) "Sinıf Öğretmeni Adaylarının Öğrenme Stilleri ile Fen Başarıları Arasındaki İlişki" isimli çalışmalarında öğretmen adaylarının öğrenme stilleri profilleri belirleyerek, öğrenme stilleri 
ile fen dersleri akademik başarısı arasındaki ilişki tespit edilmeye çalışılmışlardır. Araştırma sonucunda öğretmen adaylarının öğrenme stilleri ile cinsiyet ve fen dersleri akademik başarıları arasında anlamlı bir ilişki saptayamamışlardır.

Palas Aktaş, ve Mirzeoğlu (2009:1-8), "Illköğretim II. Kademe Öğrencilerinin Öğrenme Stillerinin Okul Başarılarına ve Beden Eğitimi Dersine Yönelik Tutumlarına Etkisi", isimli çalışmalarında araştırmaya katılan toplam öğrencilerin en çok tercih ettikleri öğrenme stili Değiştiren öğrenme stili olduğunu ve öğrencinin beden eğitimi dersine karşı tutumlarının sahip oldukları öğrenme stiline göre manidar düzeyde farklı olduğu belirlemişlerdir.

Ergür, (2010:173-184), “Hazırlık Sınıfı Öğrencilerinin Kişisel Özelliklerinin Öğrenme Stillerine Etkisi ve Öğretim Sürecine Yansıması", isimli çalışmasında öğrencilerin genel olarak özümseyen ve ayrıştıran öğrenme stillerini tercih ettiklerini ve öğrencilerin cinsiyetlerine, yaş gruplarına ve üniversiteye giriş puan türüne göre öğrenme stilleri arasında fark olmadığ1 tespit etmiştir. Ancak Ergür, Fen Liselerinden mezun olan öğrencilerin ayrıştıran, diğer lise gruplarından mezun olan öğrencilerin ise özümseyen öğrenme stilini benimsedikleri ifade etmektedir.

Mutlu (2005:1-24), Öğrenme Stillerine Dayalı Fen Bilgisi Öğretimi, isimli çalışmasının sonucunda, Fen Bilgisi öğretmenlerinin öğrencilerin öğrenme stillerini çok fazla dikkate almadıkları ve araştırmaya katılan öğrencilerin en çok İkinci Tip Öğrenenler (Analitik Öğrenenler) stilinde olduğu tespit etmiştir.

\section{Sonuçlar ve Öneriler}

Öğrenme stilleri ile ilgili alan yazını incelendiğinde bağımlı değişkenlerle öğrenme stilleri arasında genellikle anlamlı bir ilişki saptanamamaktadır. Bu çalışmada da nitekim benzer bir sonuç çıkmıştır. Ortaöğretim öğrencilerinin harita beceri düzey puanları ile onların sahip oldukları öğrenme stilleri arasında, anlamlı bir ilişki saptanamamıştır. Ancak öğrenme stilleri ile harita beceri düzeyleri arasında anlamlı bir ilişki tespit edilseydi, ortaöğretim öğrencilerinin harita beceri düzeylerini artırmada olumlu bir gelişme olabilirdi. Harita becerilerini geliştirici alternatif yol ve yöntemlerde çeşitliliğe gidilebilirdi. Bu açıdan bakıldığında başka bir yerleşim yerinde farklı katılımcılarla bu çalışmanın tekrarlanmasında fayda vardır. 
Ortaöğretim öğrencilerinin toplam harita beceri düzey puanları ile okul türü değişkeni arasında anlamlı bir ilişki belirlenmiştir. Bu anlamlı farklılık fen ve anadolu lisesi öğrencilerinin lehinedir.

Çalışma grubunda yer alan ortaöğretim öğrencilerinde baskın olan öğrenme stili özümseyendir. Bunu sırası ile değiştiren, ayrıştıran ve yerleştiren öğrenme stilleri takip etmektedir. (Tablo 1). Türkiye'de yapılan öğrenme stili ile ilgili çalışmalar incelendiğinde genellikle katılımcıların baskın öğrenme stillerinin özümseyen ve ayrıştıran olduğu dikkat çekmektedir. Ergür (2010), Yazıcı ve Sulak (2008) ve Özen (2011)'in buldukları sonuçlar bu araştırmanın sonucu ile büyük ölçüde benzerlik göstermektedir.

\section{Kaynakça}

Aşkar P. ve Akkoyunlu B. (1993). "Kolb Öğrenme Stili Envanteri”. Eğitim ve Bilim, 87, 37-47.

Babadoğan, C. (2000). Öğretim Stili Odaklı Ders Tasarımı Geliştirme, Milli Eğitim ve Sosyal Bilimler Dergisi, 147,61-63.

Bahar, H.H, Özen Y. ve Gülaçtı, F. (2009). Eğitim Fakültesi Öğrencilerinin Cinsiyet ve Branşa Göre Akademik Başarı Durumları İle Öğrenme Stillerinin İncelenmesi, Ankara Üniversitesi Eğitim Bilimleri Fakültesi Dergisi, 2009, 42(1): 69-86.

Baykara Pehlivan, K., (2010), Öğretmen Adaylarının Öğrenme Stilleri ve Öğretmenlik Mesleğine Yönelik Tutumları Üzerine Bir Çalışma, İlköğretim Online, 9(2), 749-763.

Demirkaya, H., Çetin T. \& Tokcan H. (2004). İlköğretim Birinci Kademe Öğrencilerine Yön Kavramı Öğretiminde Kullanılabilecek Metotlar, GÜ, Gazi Eğitim Fakültesi Dergisi, Cilt 24, Sayı: 3, Ankara.

Demirkaya H. (2003). Coğrafya Öğretiminde 4MAT Öğretim Sisteminin Lise Coğrafya Derslerindeki Başarı ve Tutumlar 
Uşak Üniversitesi Sosyal Bilimler Dergisi

$2013,6 / 4$

H. KOÇ

Üzerine Etkisi, GÜ, Eğitim Bilimleri Enstitüsü, Yayımlanmamış Doktora Tezi, Ankara.

Ergür, D.O., (2010). Hazırlık Sınıfı Öğrencilerinin Kişisel

Özelliklerinin Öğrenme Stillerine Etkisi ve Öğretim Sürecine Yansıması, Hacettepe Üniversitesi Eğitim Fakültesi Dergisi (H. U. Journal of Education) 39, 173-184.

Karasar, N.(2000). Bilimsel Araştırma Yöntemi (10.Baskı). Nobel Yayın ve Dağıtım Ankara

Kaya A., Bozaslan H. \& Durdukoca Ş.F. (2012). Öğretmen Adaylarının Öğrenme Stilleri İle Ders Çalışma Alışkanları Arasındaki İlişkinin İncelenmesi, Elektronik Sosyal Bilimler Dergisi, Cilt:41, sayı:41,131-146.

Koç, H. (2008). Coğrafya Öğretim Programındaki Kazanımların Öğrencilerin Harita Beceri Düzeyleri Üzerine Etkisi, Gazi Üniversitesi, Eğitim Bilimleri Enstitüsü, Orta Öğretim Sosyal Alanlar Ana Bilim Dalı, Coğrafya Öğretmenliği Bilim Dalı, Yayınlanmamış Doktora Tezi, Ankara.

Koç, H. (2010). Coğrafya Eğitiminde Harita Algısı ve Kullanımı, Milli Eğitim Dergisi, 187:146-158.

MEB (2005). Coğrafya Dersi Öğretim Programı, Ankara: M.EB Basımevi.

McCarthy, B. (1985). What 4 MAT Training Teaches us About Staff Development. Educational Leadership, 42(7):61-68.

McClure, R.W.(1992). A Conceptual Model for Map Skills Curriculum Development Based Upon A Cognitive Field Theory Philosophy, Oklahoma State University (Yayınlanmamış Doktora Tezi), Oklahoma.

Mutlu, M. (2005). Öğrenme Stillerine Dayalı Fen Bilgisi Öğretimi, Yüzüncü Yıl Üniversitesi, Eğitim Fakültesi Dergisi, 2(2):1-24. 
Uşak Üniversitesi Sosyal Bilimler Dergisi

$2013,6 / 4$

H. KOÇ

Özen, Y. (2011). Sosyal Bilgiler Eğitimi Öğretmenliği Öğrencilerinin

Öğrenme Stilleri ve Bunların Çeşitli Değişkenlerle İlişkisi,

Akademik Bakış Dergisi, 24, 1-20.

Palas Aktaş, İ.P \& Mirzeoğlu, D. (2009). İlköğretim II. Kademe

Öğrencilerinin Öğrenme Stillerinin Okul Başarılarına ve Beden Eğitimi Dersine Yönelik Tutumlarına Etkisi,

Spormetre Beden Eğitimi ve Spor Bilimleri Dergisi, VII (1): 1-

8.

Peker, M. \& Aydın, B. (2003). Anadolu ve Fen Liselerindeki

Öğrencilerin Öğrenme Stilleri, Pamukkale Üniversitesi

Eğitim Fakültesi Dergisi, 2(14):167-172.

Sanır, F. (2000). Coğrafya Terimler Sözlügü̈, Ankara: Gazi Büro

Kitapevi.

Şenyuva, E.A. (2009). Hemşirelik Öğrencilerinin Öğrenme Stillerinin

Bazı Değişkenler Açısından İncelenmesi, Kuram ve

Uygulamada Eğitim Yönetimi, 15(58): 247-271.

Ünlü, M., Üçışık, S. \& Özey, R. (2002).Coğrafya Eğitim ve

Öğretiminde Haritaların Önemi. Marmara Coğrafya Dergisi, S.5, sh.9-25. İstanbul.

Yazıcı, E. ve Sulak, H. (2008). Öğrenme Stilleri ile İlköğretim Beşinci Sınıf Matematik Dersindeki Başarı Arasındaki İlişki, Selçuk Üniversitesi Ahmet Keleşoğlu Eğitim Fakültesi Dergisi Sayı: 25, Sayfa $217-236$.

Yazıcılar, Ö. ve Güven, B. (2009). Öğrenme Stili Özelliklerinin Dikkate Alındığı Öğretim Etkinliklerini Uygulamanın Akademik Başarı, Tutumlar ve Hatırda Tutma Düzeyi Üzerindeki Etkisi, Elementary Education Online, 8(1), 9-23.

Yenice, N. ve Saracaoğlu, A.S., (2009). Sınıf Öğretmeni Adaylarının Öğrenme Stilleri ile Fen Başarıları Arasındaki İlişki, Yüzüncü Yıl Üniversitesi, Eğitim Fakültesi Dergisi, Cilt:V1, Sayı:I, 162-173. http://efdergi.yyu.edu.tr 
Uşak Üniversitesi Sosyal Bilimler Dergisi

$2013,6 / 4$

H. KOÇ

Weeden, P. (1997). Learning Through Maps, London: Routledge Ltd.

Wiegand, P.(2006). Learning and Teaching with Maps, New York: Routledge Ltd. 